\title{
Contributions of Florence Nightingale as a social entrepreneur: from modern to contemporary nursing
}

\author{
Contribuições de florence nightingale como empreendedora social: da enfermagem moderna à contemporânea \\ Contribuciones de Florence Nightingale como emprendedor social: de la enfermería moderna a la contemporánea
}

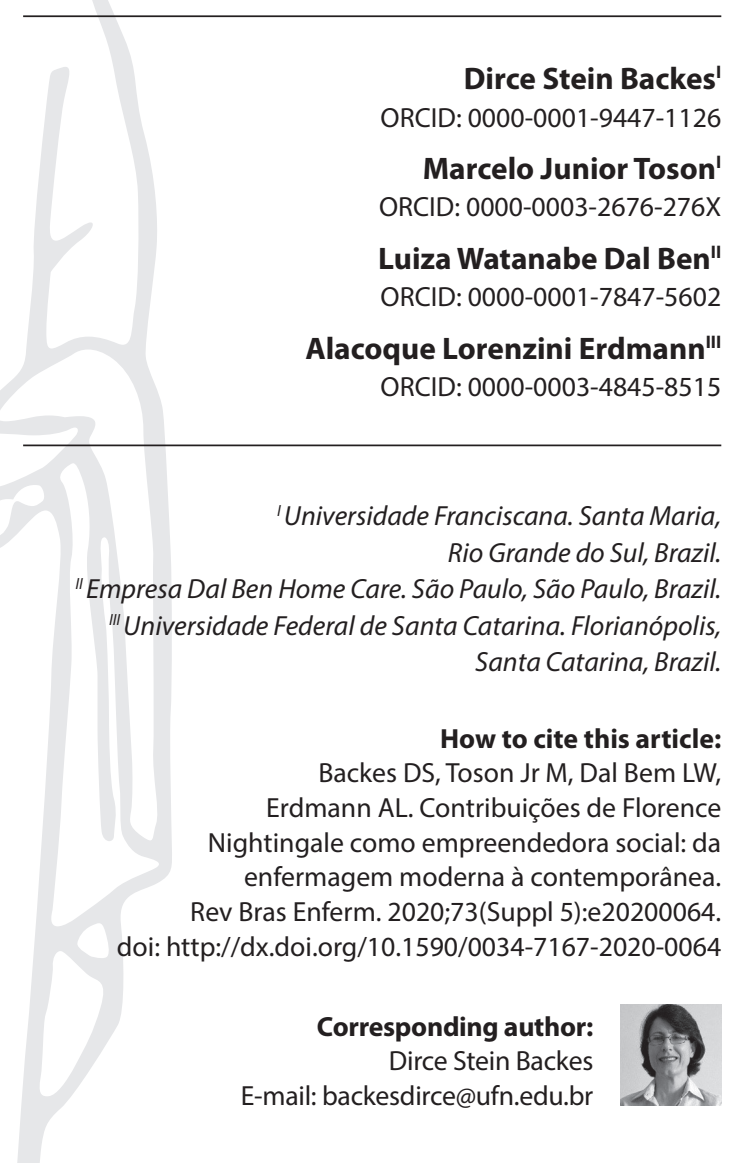

EDITOR IN CHIEF: Antonio José De Almeida Filho ASSOCIATE EDITOR: Rafael Silva

Submission: $03-28-2020$

Approval: 06-09-2020

\begin{abstract}
Objective: To reflect on the transformations of modern and contemporary nursing as well as on Florence Nightingale's social entrepreneurship. Method: This is a logical-reflective exhibition, with an emphasis on the theoretical assumptions of social entrepreneurship and the legacy of Florence Nightingale, from modern to contemporary nursing, based on readings of texts extracted from electronic databases, especially periodicals, books and theses. Results: The logical-reflective exhibition focuses on two fundamental aspects: 1) Florence Nightingale's legacy as a social entrepreneur; 2) The evolution of Brazilian nursing: from modernity to contemporaneity. Final considerations: Florence Nightingale's legacy is undeniable with regard to the evolution of modern and contemporary nursing and transcends different areas of knowledge. In addition to being a precursor to modern nursing, it is distinguished by its visionary attitude, humanitarian social value and potential for transforming the paths and realities present in the Contemporary Era.
\end{abstract}

Descriptors: Nursing; Modern History; Nursing Care; Nurse's Role; Contributions.

\section{RESUMO}

Objetivo: Refletir sobre as transformações da enfermagem moderna e contemporânea bem como sobre o empreendedorismo social de Florence Nightingale. Método: Trata-se de uma exposição lógico-reflexiva, com ênfase nos pressupostos teóricos do empreendedorismo social e do legado de Florence Nightingale, da enfermagem moderna à contemporânea, apoiando-se em leituras de textos extraídos em bases de dados eletrônicas, especialmente periódicos, livros e teses. Resultados: A exposição lógico-reflexiva centra-se em dois aspectos fundamentais: 1) O legado de Florence Nightingale como empreendedora social; 2) A evolução da enfermagem brasileira: da modernidade à contemporaneidade. Considerações finais: $\mathrm{O}$ legado de Florence Nightingale é inegável no que tange à evolução da enfermagem moderna e contemporânea e transcende as diferentes áreas do conhecimento. Além de precursora da enfermagem moderna, ela se distingue pela atitude visionária, valor social humanitário e potencial transformador de percursos e realidades presentes na Era Contemporânea. Descritores: Enfermagem; História Moderna; Cuidados de Enfermagem; Papel do Profissional de Enfermagem; Contribuições.

\section{RESUMEN}

Objetivo: Reflexionar sobre las transformaciones de la enfermería moderna y contemporánea así como sobre el espíritu empresarial social de Florence Nightingale. Método: Se trata de una exposición lógico-reflexiva, con énfasis en los presupuestos teóricos del espíritu empresarial social y del legado de Florence Nightingale, de la enfermería moderna a la contemporánea, apoyándose en las lecturas de textos extraídos en las bases de datos electrónicas, especialmente periódicos, libros y tesis. Resultados: La exposición lógicoreflexiva se centra en dos aspectos fundamentales: 1) El legado de Florence Nightingale como emprendedora social; 2) La evolución de la enfermería brasileña: de la modernidad a la contemporaneidad. Consideraciones finales: El legado de Florence Nightingale es innegable en lo que atañe a la evolución de la enfermería moderna y contemporánea y transciende las diferentes áreas del conocimiento. Además de precursora de la enfermería moderna, ella se distingue por la actitud visionaria, valor social humanitario y potencial transformador de recurridos y realidades presentes en la Era Contemporánea.

Descriptores: Enfermería; Historia Moderna; Cuidados de Enfermería; Papel del Profesional de Enfermería; Contribuciones. 


\section{INTRODUCTION}

With the Nursing Now campaign, the year 2020 was designated internationally as the year of nursing. What should actually be celebrated this year? What advances should be recognized and recorded in Florence Nightingale's 200 years? What progress has been made in the area of women and children in 25 years of recommendations from international organizations?

In his book "How to Change the World: Social Entrepreneurs and the Power of New Ideas"(1), the author highlights Florence Nightingale, precursor of modern nursing, as the protagonist of important improvements in public health worldwide. For him, her social entrepreneurship is not only distinguished by its sensitivity in helping the soldiers affected in the Crimean war, an attitude that is in itself exemplary, but also, in its context, by the initiative, determination and political influence in transforming a reality considered precarious to the introduction of safety measures in health care, such as hygiene, sanitation and comfort, which reflected in good practices beyond the nursing area.

Nightingale was decorated, at the international level, for the ability to transcend prejudices related to the activities performed by women, to overcome the charitable and assistentialist idea of care, to give voice to silence to as many as dedicated to informal care, to highlight nursing as a profession and / or specialized occupation. She has therefore become a character of herself and a landmark for humanity by being included among the 100 most influential women in the world $^{(2-3)}$.

Other entrepreneurial examples such as those of Florence Nightingale are multiplying in Brazil and in the world, in the Modern and Contemporary Era. These are close experiences, but they have not always received due social recognition. At the national level, names like Ana Nery and Wanda de Aguiar Horta can be evoked. Ana Nery, first Brazilian nurse, magnified by her strong humanitarian spirit in caring for Paraguayan and Brazilian soldiers during the Paraguayan War, in 1865, in which she voluntarily enlisted. She had her name written in the Book of Heroes, which highlights personalities of Brazilian history. And Wanda de Aguiar Horta, recognized for her innovative character in the process of consolidating the scientific bases of Brazilian nursing, through the development of the Theory of Basic Human Needs. Parallel to the role of Nightingale, these and other visionary initiatives need to be enhanced and made visible, nationally and internationally, in order to add social and political value to the profession ${ }^{(4)}$.

Amidst these and other countless entrepreneurial stories in Brazilian and global nursing, it is questioned: What was Florence Nightingale's legacy as a social entrepreneur for modern and contemporary nursing? Here, it is understood by social entrepreneurship of nursing, the attitude of promoting the healthy living of individuals, families and communities through interactive and associative processes with a view to their emancipation as protagonists of their own history ${ }^{(5)}$; and, for modernity and contemporaneity, the temporal periods marked by intense and profound transformations in the different fields and dimensions of society. Modernity is configured as a set of terms that narrated the form. Contemporary life, on the other hand, refers to the history of the present time, focused on the analysis of the ruptures and permanencies of the past in the present; it is characterized by industrial development, globalization, intense urban and population growth, technological progress in different areas and improvement of conditions and prolongation of life expectancy, among other advances and setbacks ${ }^{(6)}$.

\section{OBJECTIVE}

Reflect on the transformations of modern and contemporary nursing as well as on Florence Nightingale's social entrepreneurship.

\section{METHODS}

It is a logical-reflective exhibition, with an emphasis on the theoretical assumptions of social entrepreneurship and Florence Nightingale's legacy, from modern to contemporary nursing, based on readings of texts extracted from electronic databases, especially periodicals, books and theses.

It seeks to portray, in the composition of this essay, connections between an undeniable past of Nightingale's thinking and acting and its entrepreneurial attributes as the protagonist of a new history for modern and contemporary nursing. It also seeks to demonstrate the individual and collective value of nursing as fundamental to defend the necessary change in the nursing workforce and in healthcare environments.

\section{FROM FLORENCE NIGHTINGALE TO CONTEMPORARY NURSING}

The logical-reflective exhibition focuses on two fundamental aspects: Florence Nightingale's legacy as a social entrepreneur; and the evolution of Brazilian nursing: from modernity to contemporaneity.

\section{Florence Nightingale's legacy as a social entrepreneur}

Advances in different areas of knowledge were possible thanks to the boldness of visionary people, that is, who innovated in their way of thinking and acting, adding individual and collective value; to the audacity of people who were able to break paradigms and transcend institutionalized limits and principles. It is in this profile of entrepreneurial people, therefore, that Florence Nightingale, precursor of modern nursing, stands, whose entrepreneurial profile traced traditional models and conceived new ways of being and promoting nursing care, in its uniqueness and multidimensionality.

Social entrepreneurship is, therefore, an emerging paradigm of a new development model, focusing on the human, social and sustainable dimension. It refers to an agent that induces and generates self-organization of the social system, therefore, capable of adding value of social impact. It is characterized by employing dynamic strategies to trigger local actions with global reach. In this sense, social entrepreneurship generates social transformation and emancipation, in addition to professional empowerment, of which Nightingale is an example ${ }^{(5,7)}$.

In this sense, social entrepreneurship generates social transformation and emancipation, in addition to professional empowerment, of which Nightingale is an example. The legacy left by 
the precursor of modern nursing is notorious and recognized by several areas of knowledge. In addition to conceiving and imparting social and scientific value to nursing care, Nightingale pushed her successors to a new professional ideal, that is, a new way of educating, informing and persuading the government and the public for the needs of structural and organizational changes ${ }^{(3)}$.

From this perspective, Nightingale's entrepreneurial journey echoed both socially, politically and economically. If in the social realm it added humanitarian value, in the political and economic realm it enabled new spaces for the insertion of nurses, including with competitive and sustainability potential. Under this focus, social entrepreneurs stand out for their ability to generate results, even in the midst of adversities of all kinds.

Social entrepreneurs focus on solving social problems that, using principles of business management, innovation and creativity, develop creative solutions and bring about transformations, especially in those invisible or promising realities ${ }^{(2-3)}$. They are dedicated to a social mission, par excellence, as did Nightingale, a pioneer in medical assistance and reform, as well as driving improvements in public health around the world.

She was, therefore, an entrepreneur who distinguished herself by determination, visionary ability and daring to take risks. Her determination for social causes prompted her to care for sick and wounded soldiers in Crimea and to abdicate a social nobility role that she had inherited from her family. Far beyond reorganizing nursing and saving lives during the war, it was projected, on the world stage, by its proactive leadership and political authority, which enabled it to stand out among the 100 most influential women in world history ${ }^{(3)}$.

Social entrepreneurship requires unusual professionals, that is, capable of perceiving opportunities amid contradictions, of perceiving uncertainties among the certainties of this world, to perceive the possibility of initiating processes, like Florence Nightingale, instead of just continuing and / or reproducing protocols. This entrepreneurial spirit, in addition to being a proactive behavior, is also a mental attitude that includes motivation and the ability to identify and lead new possibilities for social intervention, based on a systemic-complex view of reality.

\section{The evolution of Brazilian nursing: from modernity to contemporaneity}

Modern and contemporary Brazilian nursing has several reasons to celebrate its achievements and project itself as the profession of the future. First, because it is a profession that has a broad understanding of reality, that is, an understanding of human needs in the integrality of being and in its social context. Second, due to its visionary potential to explore new social fields, there is no need to submit to traditional care spaces, in which, in most cases, the notion of illness prevails. And yet, due to the fact that women have the possibility to conduct their own business and obtain acceptance and legitimacy in what they undertake, considering that, in nursing, the vast majority are women ${ }^{(5,8)}$.

Brazilian nursing has been assuming a prospective leadership in identifying the population's care needs, as well as in promoting and protecting the health of users in its different dimensions, especially due to its proactive and resolute insertion in different contexts. Constituted by a contingent of more than 2 million professionals, present in the 5,570 municipalities, in the 27 units of the Federation ${ }^{(9)}$, nursing has been establishing itself as the profession of the future, by promoting public policies and health interventions that aim, above all, to consolidate the principles and guidelines of the Unified Health System ${ }^{(10)}$.

Several initiatives associated with nursing entrepreneurship can already be seen at the national level, even though the focus is still strongly associated with business understanding. One reason for this is that social entrepreneurship has received little attention, and initiatives in the social sphere do not have an immediate impact or even receive the desired value ${ }^{(5,10)}$. In this sense, social entrepreneurship gradually raises new questions, new discussions, especially when associated with nursing/health care practices. It is necessary to multiply the initiatives and support entrepreneurial nursing care, which generates controversies and doubts, starting with the debate on the theme and the construction of specific references for the area.

Nursing care as an entrepreneurial social practice can be evidenced in the most different movements and spaces of the nursing professional's practice. It can be noticed in multiple spaces and in the dynamics of social organization of care, as well as in the interactive human and technical-political skills of nurses. Therefore, nursing has multiple skills and a broad and socially recognized field of action, but it needs to be bold, in the sense of investing in professional training and exploring opportunities and new spaces, understanding that being an entrepreneur is being able to explore opportunities and lead new fields and professional practice. It means having the ability to imagine, develop and materialize visions, in which the concepts of self, synergy, leadership and the system of relationships / interactions are fundamental elements ${ }^{(3,5)}$.

The changes in the nursing field initiated by Florence Nightingale emerge from social problems and constitute an integral part of a global movement, with the purpose of improving the conditions of human life. Following her example, countless Brazilian nurses define themselves as entrepreneurs, for taking responsibility and risk to create opportunities, in addition to having talent, competence and leadership to foster innovative management and intervention processes in order to contribute prospectively to the improvement of public health ${ }^{(7)}$.

The legacy left by Florence Nightingale elucidates the importance of entrepreneurial behavior in the genesis of proposals of social value. Her entrepreneurial legacy for modern and contemporary nursing is clear and convincing, as it has spread to her successors a new way of caring and managing care environments, that is, she pathed her own professional career, which makes her, today, recognized among the most influential women in human history. As a nurse, politician and manager, she was effectively a prominent social entrepreneur who, despite her non-conformity, took on a fearless and visionary stance in solving social and health problems.

\section{Study limitations}

As a limitation of this study, few references are considered with a focus on social entrepreneurship in nursing, both nationally and internationally. 


\section{Contributions to the field of Nursing}

The main contribution of this study is to give visibility to the evolution of nursing in Florence Nightingale's 200 years. Another contribution is to call attention to this pioneer, whose entrepreneurial profile went back to traditional models and conceived new ways of being and promoting nursing care, in its uniqueness and multidimensionality. Still, this work induces an entrepreneurial culture in the nursing area, as well as stimulating new theoretical methodological approaches to social intervention, with a view to advancing nursing science. It shows, in particular, the need to train nurses for social entrepreneurship, which implies, according to this view, to train critical, flexible and proactive professionals for what is new and different, that is, professionals capable of identifying opportunities amid contradictions and thus enabling a new organization at the local and global level.

\section{FINAL CONSIDERATIONS}

Florence Nightingale's legacy is undeniable with regard to the evolution of modern and contemporary nursing and transcends different areas of knowledge. In addition to being a precursor to modern nursing, it is distinguished by its visionary attitude, humanitarian social value and potential for transforming paths and realities present in the contemporary era.

Social entrepreneurship can be characterized as a new way of acting and interacting with the various segments of society, that is, as a new approach, capable of adding social value and inducing political and economic transformations. Hence the need for higher education institutions to create integrative strategies that aim to foster, stimulate and develop the entrepreneurial spirit of their students, through new attitudes and behaviors, necessary to face current and future challenges.

To reflect on Florence Nightingale's legacy is to reaffirm the social value of modern and contemporary nursing, re-found its definition and reinvigorate the discipline's philosophical values, especially with regard to its perceived social mission. In short, it is expected that, in a year of the Nursing Now campaign, the legacy of this precursor figure will serve as inspiration and encouragement for nurses to continue to lead the way in improving public health worldwide.

\section{FUNDING}

Project financed by the Public Notice / Call "Productivity in Research CNPq", under the title: "Nursing care as a socially entrepreneurial practice". CNPq process: 302103 / 2017-1.

\section{REFERENCES}

1. Bornstein D. How to Change the World: Social Entrepreneurs and the Power of new Ideas. New York: Oxford University Press; 2007.384 p.

2. Frello AT, Carraro TE. Florence Nightingale's contributions: an integrative review of the literature. Esc Anna Nery. 2013;17(3):573-9. doi: $10.1590 /$ S1414-81452013000300024

3. Hoyt S. Florence Nightingale's Contribution to Contemporary Nursing Ethics. J Holist Nurs. 2010;28(4):331-2. doi: $10.1177 / 0898010110383281$

4. Cardoso MMVN, Miranda CML. Anna Justina Ferreira Nery: um marco na história da enfermagem brasileira. Rev Bras Enferm [Internet]. 1999 [cited 2020 Jan 27];52(3):339-48. Available from: http://www.scielo.br/pdf/reben/v52n3/v52n3a03.pdf

5. Backes DS, Zamberlan C, Colomé J, Souza MT, Marchiori MT, Lorenzini AE, et al. Systemic Interactivity between Interdependent Concepts of Nursing Care. Aquichan. 2016;16(1):24-31. doi: 10.5294/AQUI.2016.16.1.4

6. Simyan T, Kačāne I. Towards the Understanding of the Concepts "Modernity," "Modernism" and "Avant-Gardism” in (Post)-Soviet and German Literary Theory (An Attempt of Terminological Unification). KnE Social Sci. 2018; 3(7):1-31. doi: 10.18502/kss.v3i7.2462

7. Backes DS, Ilha S, Weissheimer AS, Halberstadt BMK, Megier ER, Machado R. Socially entrepreneurial activities in nursing: contributions to health/healthy living. Esc Anna Nery. 2016;20(1):77-82. doi: 10.5935/1414-8145.20160011

8. Andrade AC, Dal Ben LW, Sanna MC. Entrepreneurship in Nursing: overview of companies in the State of São Paulo. Rev Bras Enferm [Internet]. 2015 [cited 2020 Jan 19];68(1):40-4. Available from: http://www.scielo.br/pdf/reben/v68n1/en_0034-7167-reben-68-01-0040.pdf

9. Silva MCN, Machado MH. Health and Work System: challenges for the Nursing in Brazil. Ciênc Saúde Coletiva. 2020;25(1):7-13. doi: $10.1590 / 1413-81232020251.27572019$

10. Lomba MLLF, Toson M, Weissheimer AS, Backes MTS, Büscher A, Backes DS. Social entrepreneurship: translation of knowledge and practices in Brazilian nursing students. Rev Enf Ref. 2018;serIV(19):107-15. doi: 10.12707/RIV18064 